\title{
Hubungan Belajar Online di Masa Pandemi Covid 19 dengan Tingkat Stress Mahasiswa S1 Keperawatan STIKes Baiturrahim Jambi
}

\author{
Fadhil Ammar Adrian', Vevi Suryenti Putri ${ }^{2}$, Martha Suri ${ }^{3}$ \\ ${ }^{1-3}$ Program Studi S1 Imu Keperawatan Sekolah Tinggi Ilmu Kesehatan Baiturrahim Jambi \\ Email:Fadhilammar37@gmail.com
}

Submitted : 25/08/2020

Accepted: 06/01/2021

Published: $06 / 03 / 2021$

\begin{abstract}
As a result of the global Covid-19 pandemic, all campuses are being led to conduct online or online lectures in order to break the chain of Covid-19 spread.Online learning is a type of teaching-learning activity with technology that is carried out remotely. All elements ranging from lecturers, staff, and students must adapt to this condition. This sudden change can certainly cause stress to studentsmethodThis researchuses a quantitative research method with a cross-sectional. The population in this study were undergraduate nursing students at STIKes Baiturrahim Jambi. The researchwas conducted online by filling out questionnaires via google form. The data obtained were analyzed univariately and bivariately using the chi square test, the study was conducted on 23-24 June 2020. The results of 57 respondents as many as 25 (43.9\%) learning online is not good and as many as 32 (56.1\%) learning online is good. Online learning of the majority of undergraduate nursing students is good. Of the 57 respondents, 32 (56.1\%) had light stress levels, $16(28.1 \%)$ moderate stress levels and $9(15.8 \%)$ severe stress levels. The results of statistical tests obtained p-value $=0,000$..The conclusion is that there is a relationship between online learning and the stress level of S1 Nursing STIKES Baiturrahim Jambi students.
\end{abstract}

Keywords: online learning, stress level, students

\begin{abstract}
Abstrak
Akibat pandemi global Covid-19 ini semua kampus digiring untuk melakukan perkuliahan daring atau online dalam rangka memutus mata rantai penyebaran Covid-19. Belajar onlinemerupakan jenis kegiatan belajar-mengajar dengan teknilogi yang dilakukan dari jarak jauh.Semua elemen mulai dari dosen, ketenagaan, dan mahasiswa harus beradaptasi terhadap kondisi ini. Perubahan yang terjadi secara tiba-tiba ini tentu dapat menimbulkan stres tersediri bagi mahasiswa. Penelitian ini Bertujuan Untuk mengetahui Hubungan Belajar online dengan tingkat stress mahasiswa S1 Keperawatan STIKBA Jambi. Penelitian ini menggunakan metode penelitian kuantitatif dengan pendekatan cross sectsional Populasi dalam penelitian ini adalah mahasiswa S1 Keperawatan di STIKes Baiturrahim Jambi, jumlah sampel dalam penelitian ini sebanyak 57orang, Penelitian dilakukan secara online dengan cara pengisian kusioner melalui google form. Data dianlisis secara univariat dan bivariat menggunakan uji chi square, penelitian dilakukan pada tanggal 23-24 Juni 2020. Hasil,dari 57 responden sebanyak 25 (43,9\%) belajar online kurang baik dan sebanyak 32 $(56,1 \%)$ belajar online baik. Belajar online mahasiswa S1 Keperawatan mayoritas baik.dari 57 responden sebanyak $32(56,1 \%)$ tingkat stres ringan, sebanyak $16(28,1 \%)$ tingkat stres sedang dan $9(15,8 \%)$ tingkat stres berat. Hasil uji statistik diperoleh nilai $\mathrm{p}$-value $=0,000$.ada hubungan belajar online dengan tingkat stresmahasiswa S1 Keperawatan STIKES Baiturrahim Jambi.
\end{abstract}

Kata Kunci : belajar online, mahasiswa, tingkat stres 


\section{PENDAHULUAN}

Keadaan dunia saat ini digemparkan oleh informasi mengenai virus mematikan ke 7 dunia yang menyebar secara pesat ke beberapa wilayah belahan dunia saat ini. Virus tersebut di kenal dengan nama Virus Corona (Covid-19) yang adalah jenis baru yang menular ke manusia yang menyerang gangguan pada system pernapasan, sampai berujung pada kematian (Yusuf Thalia, 2020)

Penyakit menular yang disebabkan oleh sindrom pernafasan akut yang parah coronavirus,. Secara umum dikenal sebagai theororonavirus, merupakan subfamili Orthocoronavirinae, dalam keluarga Coronaviridae, urutan Nidovirales, dan ranah Riboviria (Groot, et al., 2011, p. 806). Virus corona adalah sekelompok virus terkait yang menyebabkan penyakit pada mamalia dan burung. Pada manusia, virus corona menyebabkan infeksi saluran pernapasan yang dapat berkisar dari ringan hingga mematikan. Penyakit ringan mencakup beberapa kasus flu biasa (yang memiliki kemungkinan penyebab lain, terutama rhinovirus), sementara varietas yang lebih mematikan dapat menyebabkan SARS, MERS, dan COVID-19 (Ilmiyah, 2020). Gejala pada spesies lain bervariasi: pada ayam, mereka menyebabkan penyakit saluran pernapasan atas, sedangkan pada sapi dan babi mereka menyebabkan diare. Belum ada vaksin atau obat antivirus untuk mencegah atau mengobati infeksi coronavirus manusia. (Setiawan A.R, 2020) COVID-19 pertama kali diidentifikasi pada Desember 2019 di Wuhan, ibu kota provinsi Hubei China, dan sejak itu menyebar secara global, mengakibatkan pandemi virus coronavirus 2019-20 yang sedang berlangsung (Hui, et al., 2020, p. 264). $2019-20$ pandemi coronavirus dilaporkan telah menyebar ke Indonesia pada tanggal 2 Maret 2020, 4 hari setelah wakil presiden Indonesia menyatakan bahwa Indonesia menghindari Coronavirus.(Setiawan A.R 2020)
COVID-19 menyebar ke Indonesia ketika seorang instruktur tari dan ibunya terinfeksi dari warga negara Jepang (Ratcliffe, 2020). Pada 9 April, pandemi telah menyebar ke semua provinsi di Indonesia setelah Gorontalo mengkonfirmasi kasus pertamanya, dengan Jakarta, Jawa Barat, dan Jawa Timur menjadi provinsi yang paling terpukul. Sejauh ini tanggal 7 Agustus, Indonesia telah mencatat 119.000 kasus positif dan 5.521 kematian. Para peneliti mengemukakan alasan utama tingginya angka ini mungkin karena kurangnya pengujian, sehingga banyak kasus tidak terdeteksi (Barker \& Souisa, 2020)

Tanda dan gejala umum infeksi COVID-19 antara lain gejala gangguan pernapasan akut seperti demam, batuk dan sesak napas. Masa inkubasi rata-rata 5-6 hari dengan masa inkubasi terpanjang 14 hari. Pada kasus COVID-19 yang berat dapat menyebabkan pneumonia, sindrom pernapasan akut, gagal ginjal, dan bahkan kematian. Tanda-tanda dan gejala klinis yang dilaporkan pada sebagian besar kasus adalah demam, dengan beberapa kasus mengalami kesulitan bernapas, dan hasil rontgen menunjukkan infiltrat pneumonia luas di kedua paru. (Kemenkes RI 2020)

Tingginya angka kejadian dan potensi kematian membuat banyak pihak berusaha memutuskan rantai penularan Covid-19 ini dengan berbagai cara, seperti penerapan PSBB, perubahan sistem sekolah dan perkuliahan menjadi system daring, dan himbauan kepada seluruh masyarakat untuk menggunakan masker.Pemerintah telah melakukan semua tahapan manajemen krisis di bidang pendidikan sebagai upaya penanganan kondisi darurat Covid19.Langkah berikutnya pemerintah mengeluarkan program krisis berupa Study From Home (SFH). Program ini merupakan jenis kegiatan belajar-mengajar yang dilakukan dari jarak jauh atau pelaksanaan belajar dari rumah. Mengingat karakteristik pembelajaran jarak jauh tersebut maka 
diberlakukan satu sistem pembelajaran online. Teknologi online diharapkan mampu menjadi solusi sebagai media pembelajaran selama pandemi Covid19.(Hidayat \& Noeraida 2020)

Akibat pandemi global Covid-19 ini semua kampus digiring untuk melakukan perkuliahan daring atau online dalam rangka memutus mata rantai penyebaran Covid-19 (Tabroni, 2020). Semua elemen mulai dari dosen, ketenagaan, dan mahasiswa harus beradaptasi terhadap kondisi ini. Perubahan yang terjadi secara tibatiba ini tentu dapat menimbulkan stres tersediri bagi mahasiswa.( Sari M.K, 2020)

Semua pihak yang menjalani proses belajar mengajar secara daring menglami kepnikan : guru, dosen, murid, mahasiswa. Masalah teknis hanya menjadi satu kendala dari sekian baanyak kendala dan problem dalam proses belajar mengajar secara daring. Masalah teknis yang ditemui di lapangan beragam, mulai dari teknis pengoprasian komputer atau smartphone, kecukupan kuota, sampai dengan menjalankan aplikasi pembelajaran daring. Selain masalah teknis banyak kendala lain yang ditemuui antaarra lain menyesuaikan materi perkuliahan sesuai dengan kondisi yang luar biasa. . (Sanjaya F.R, 2020)

Hasil jajak pendapat yang dilakukan oleh salah satu mahasiswa Fakultas psikologi Unika SoegejipranataSemarang terhadap mahasiswa-mahasiswa fakultas psikologi Inuka Soegejiprinata tentang pembelajaran daring menemukan komentar positif dan negatif. Komentar positif yang didapatkan $20 \%$ dari partisipan menyatakan dengan pembelajaran daring bisa santai dan rebahan, jadi aktif bertanya, tidak malu, dan hemat transport. Komentar Negatif yang didapatkan $80 \%$ dari pasrtisipan menyatakan Tugas lebih banyaj dari pada kuliah off line, penjelasan materi masih kurang, tidak bisa diskusi, prosedurnya repot, kaget tidak terbiasa dengan daring dan beberapa masalah teknis lainya (Sanjaya F.R, 2020)
Maka hal tersebut dapat meningkatkan tuntutan akademis kepada tenaga pengajar dan juga mahasiswa. Tuntutan akademis yang harus dihadapi dan tidak siapnya individu untuk menghadapinya juga dapat mengakibatkan gangguan psikologis seperti stres. Ditambah semakin lebarnya kesenjangan sosial dan ketidakpastian situasi sosial membuat masyarakat mengalami gangguan psikologis (Ambarwati, dkk 2017)

Stres dan ketidakpuasan merupakan aspek yang tidak dapat dihindari oleh individu. Siapa pun dapat terkena stres baik anak-anak, remaja maupun dewasa. Mahasiswa termasuk golongan remaja akhir yang tidak luput dari stres. Para mahasiswa oleh orangtua dan masyarakat umum sudah dianggap dewasa dan mampu menyelesaikan masalah-masalah yang dihadapi (Lailiya Wardani, 2018)

Penelitian mengenai tingkat stres pada mahasiswa sesuai pilihan fakultas mereka telah dilakukan pada beberapa universitas di dunia. Prevalensi mahasiswa di dunia yang mengalami stres didapatkan sebesar 38-71\%, sedangkan di Asia sebesar 39,6-61,3\% (Habeeb 2010, Koochaki 2009). Sementara itu, prevalensi mahasiswa yang mengalami stres di Indonesia sendiri didapatkan sebesar 36,771,6\% (Fitasari 2011).

Mahasiswa mengalami stres dapat berdampak positif atau negatif. Peningkatan jumlah stres akademik akan menurunkan kemampuan akademik yang berpengaruh terhadap indeks prestasi. Bahkan yang dirasa terlalu berat dapat memicu gangguan memori, konsentrasi, penurunan kemampuan penyelasaian masalah, dan kemampuan akademik. (Goff. A.M, 2011). Beban stres yang dirasa berat juga dapat memicu seseorang untuk berperilaku negatif, seperti merokok, alkohol, tawuran, seks bebas bahkan penyalahgunaan NAPZA. Stres tidak hanya berdampak negatif tetapi juga memiliki dampak positif, yaitu berupa peningkatan kreativitas dan 
memicu pengembangan diri, selama stres yang dialami masih dalam batas kapasitas individu. Stres tetap dibutuhkan untuk pengembangan diri mahasiswa (Ambarwauti dkk 2017). Berdasarkan uraian di atas, maka penulis tertarik untuk meneliti tentang "Hubungan belajar online di masa pandemi covid 19 dengan Tingkat Stres mahasiswa S1 Keperawatan STIKes Baiturrahim Jambi”

\section{METODE PENILITIAN}

Penelitian ini menggunakan metode penelitian kuantitatif dengan pendekatan cross sectsional yang bertujuam untuk mengetahui Hubungan Belajar Online dengan Tingkat Stres mahasiswa S1 Keperawatan STIKes Baiturrahim Jambi, Populasi dalam penelitian ini adalah mahasiswa S1 Keperawatan di STIKes Baiturrahim Jambi, jumlah sampel dalam penelitian ini sebanyak 57orang, Penelitian dilakukan secara online dengan cara pengisian kusioner melalui google form. Data yang diperoleh dianlisis secara univariat dan bivariat menggunakan uji chi square, penelitian dilakukan pada tanggal 23-24 Juni 2020.

\section{HASIL DAN PEMBAHASAN}

\section{a. Gambaran belajar online}

Tabel 1. Gambaran belajar online mahasiswa S1 Keperawatan STIKes Baiturrahim Jambi di masa pandemi

\begin{tabular}{clcc}
\hline No & $\begin{array}{l}\text { Belajar } \\
\text { Online }\end{array}$ & Jumlah & Persentase \\
\hline $\mathbf{1}$ & $\begin{array}{l}\text { Kurang } \\
\text { Baik }\end{array}$ & 25 & 43,9 \\
\hline $\mathbf{2}$ & Baik & 32 & 56,1 \\
\hline & Total & 57 & 100 \\
\hline
\end{tabular}

Berdasarkan Tabel 1 diketahui bahwa dari 57 responden sebanyak 25 (43,9 $\%$ ) belajar online kurang baik dan sebanyak $32(56,1 \%)$ belajar online baik. Belajar online mahasiswa S1 Keperawatan mayoritas baik. Hal ini disebabkan karena hanya sebagian mahasiswa yang mengeluhkan masalah belajar online 23 $(40,4 \%)$ mahasiswa merasa saat belaajar online tugas lebih banyak dibandingkan kuliah bisa. Sebanyak 25 (43,9\%) mahasiswa sering merasa belum terbiasa dengan belajar online, Sebanyak 27 $(47,4 \%)$ Saat belajar online mahsiswa sering merasa

kurang kontak langsung, sebanyak 21 $(36,8 \%)$ dan sebanyak $30(52,6 \%)$ Orang tua mahasiswa selalu menjadi motivasi dalam belajar online.

Hal ini sejalan dengan penilitian Eko Kuntarto (2020) Model pembelajaran daring telah mampu meningkatkan penyerapan mahasiswa terhadap materi kuliah, dengan peningkatan yang mencapai lebih dari $81 \%$ dibandingkan dengan hanya menggunakan model pembelajaran tatapmuka. Berdasarkan hasil kuesioner, maahsiswa berpendapat bahwa model pembelajaran daring telah memberikan pengalaman baru yang lebih menantang daripada model pembelajaran konvensional (tatap-muka). Tak terbatas waktu dan tempat belajar memberikan mahasiswa kebebasan untuk memilih saat yang tepat dalam pembelajaran berdasarkan kepentingan mereka, sehingga kemampuan untuk menyerap bahan pembelajaran menjadi lebih tinggi daripada belajar di dalam kelas. Meskipun masih banyak terdapat beberapa kekurangan dalam belajar online.

Hal ini sejalan dengan penelitian yang dilakuakn oleh Sanjaya R (2020) Menurut Sanjaya F.R (2020). Komentar Negatif yang didapatkan dari hasil survey 80\% dari pasrtisipan menyatakan Tugas lebih banyak dari pada kuliah off line, penjelasan materi masih kurang, tidak bisa diskusi, prosedurnya repot, kaget tidak terbiasa dengan daring dan beberapa masalah teknis lainnya.

$$
\text { Menurut Rusdiana }
$$

perkuliahan daring memerlukan evaluasi 
mengenai persiapan perguruan tinggi, yang salah satunya adalah dari pengguna yakni mahasiswa, terutama terkait dengan peningkatan motivasi dan pemenuhan tujuan bersama untuk mengembangkan perkuliahan daring. Pada fasilitas penyelenggaraan pembelajaran daring mengenai dosen pada ragam aktivitas dan tool

Sistem pembelajaran daring merupakan implementasi dari pendidikan jarak jauh melalui online. Sistem pembelajaran ini pun bertujuan untuk meningkatkan pemerataan akses terhadap pembelajaran yang lebih baik dan bermutu. Sebab, dengan sistem pembelajaran daring, akan memberikan peluang bagi pelajar dan mahasiswa untuk dapat mengikuti suatu pelajaran atau mata kuliah tertentu. (Agus Yulianto, 2020).

\section{b. Gambaran Tingkat Stress}

Tabel 2. Gambaran tingkat stress mahasiswa mahasiswa S1 Keperawatan STIKes Baiturrahim Jambi di masa

\begin{tabular}{cccc}
\hline No & $\begin{array}{c}\text { Tingkat } \\
\text { Stres }\end{array}$ & $\begin{array}{c}\text { Jumla } \\
\text { h }\end{array}$ & $\begin{array}{c}\text { Persentas } \\
\text { e }\end{array}$ \\
\hline $\mathbf{1}$ & Ringan & 32 & 56,1 \\
\hline $\mathbf{2}$ & Sedang & 16 & 28,1 \\
\hline $\mathbf{3}$ & Berat & 9 & 15,8 \\
\hline & Total & 57 & 100 \\
& & &
\end{tabular}

Berdasarkan Tabel 2 diketahui bahwa dari 57 responden sebanyak 32 $(56,1 \%)$ tingkat stres ringan, sebanyak 16 $(28,1 \%)$ tingkat stres sedang dan $9(15,8 \%)$ tingkat stres berat.

Mahasiswa yang memiliki tingkat stres sedang disebabkan mahasiswa pola tidur sering tidak teratur, mahasiswa sering merasa daya konsentrasi dan daya ingat saya semakin menurun, kurang Berdasarkan hasil sebanyak $2 \quad(80 \%)$ mahasiswa memiliki belajar online yang kurang baik yang memiliki tingkat stres ringan, sebanyak 14 (56\%) mahasiswa memiliki belajar online yang kurang baik yang memiliki tingkat stres sedang, dan sebanyak 9 (36\%)mahasiswa memiliki bersemangat dalam menjalani kuliah online, dan merasa mudah lelah

Stres mempunyai arti sendiri bagi setiap orang, dimana hampir semua orang mengalami satu tingkat stres yang rumit dan kompetitif namun tidak selalu mendukung. Secara teknis, stres merupakan respon tubuh yang tidak spesifik terhadap setiap kebutuhan tubuh yang terganggu, akan berdampak secara total pada individu yaitu terhadap fisik, psikologis, intelektual, sosial dan spiritual.(Psychology Foundation of Australia, 2010).

Stressor yang dihadapi setiap orang secara teratur, biasanya tidak merusak aspek fisiologis misalnya terlalu banyak tidur, kemacetan lalu lintas, kritikan dari atasan. Situasi seperti ini biasanya berakhir dalam bebarapa menit atau jam. Stressor ini bukan risiko yang signifikan untuk timbulan gejala. Namun demikian stressor ringan yng banyak dalam waktu singkat dihadapi terus menerus dapat meningkatkan risiko penyakit. Pada mahasiswa stres ringan biasanya terjadi saat dimarahi dosen, mengalami kemacetan dan terlalu banyak tidur. Gejala dari stres ringan adalah bibir kering, bernafas terengah-engah, kesulitan menelan merasa lemas, goyah, berkeringat belebihan saat temperature normal, takut tanpa alasan yang jelas dan merasa sangat lega saat situasi berakhir, dengan demikian adanya stressor ringan dalam jumlah banyak dalam waktu singkat akan menyebabkan peningkatan risiko penyakit bagi mahasiswa (Psychology Foundation of Australia, 2010).

c. Hubungan Belajar Online di masa pandemi covid 19 dengan Tingkat Stress mahasiswa S1 Keperawatan Jambi.

belajar online yang kurang baik yang memiliki tingkat stres berat. Selain itu terdapat sebanyak $30 \quad(93,8 \%)$ mahasiswa memiliki belajar online yang baik yang memiliki tingkat stres ringan, dan sebanyak $16(28,1 \%)$ mahasiswa memiliki belajar 
online yang baik yang memiliki tingkat stres sedang,

Hal ini sejalan dengan penelitian Sari M.K (2020) yang berjudul Tingkat stress Mahsiswa S1 Keperawatan dalam mengadapi wabah covid 19 dan perkuliahan daring di STIKES Karya Husada Kediri responden pada penelitian ini mengalami tingkat stres dalam kategori sedang yaitu sebanyak 27 mahasiswa atau $(38,57 \%)$. Sedangkan 20 mahasiswa $(28,57 \%)$ mengalami stres tingkat berat, dan 23 mahasiswa $(32,86 \%)$ mengalami stress tingkat ringan., pembelajaran daring akibat mewabahnya virus Covid-19 juga menimbulkan stress tersendiri bagi mahasiswa. Hal ini tampak pada distribusi skor rata-rata tertinggi jawaban kuesioner pada nomor 19 yang berkaitan dengan kesulitan memahami materi pada perkuliahan daring.

Hasil penelitian (Pawicara dan Conilie, 2020) menunjukkan bahwa mahasiswa mengalami kejenuhan belajar dikarenakan berbagai faktor. Faktor-faktor tersebut antara lain media atau materi yang kurang menarik sehingga penyajian materi selama proses pembelajaran daring dilakukan secara monoton. Banyaknya tugas yang diberikan dengan disertai pemberian materi tanpa penjelasan mendalam. Hal tersebut menimbulkan ketidakpahaman materi pada mahasiswa. Akibatnya, timbul rasa malas, kehilangan semangat, stress, susah tidur, lelah dan bosan terhadap materi kuliah selama pembelajaran daring.

Kendala-kendala yang dihadapi oleh mahasiswa seperti jaringan yang tidak ada, paket internet yang habis, pekerjaan rumah yang harus dikerjakan juga, dan tugas perkuliahan yang menumpuk. Berbagai tuntutan akademik yang harus diselesaikan oleh mahasiswa menyebabkan mereka mengalami stres akademik. Ketidakmampuan mahasiswa untuk beradaptasi dengan keadaan tersebut membuat mereka mengalami stress (Harahap, dkk 2020)

Menurut asusmsi peneliti, mahasiswa yang memiliki belajar online yang yang baik memiliki tingkat stress ringan hal ini disebabkan karena orang tua mahasiswa selalu menjadi motivasi dalam belajar online, dan mahasiswa sering membuat catatan motivasi sebagai penyemangat

Hal ini sejalan dengan penilitian Emeralda dan (Ika 2017) Hubungan antara dukungan Orang Tua dengan motivasi belajar pada siswa Hasil analisis SpearmanRho menunjukkan koefisien korelasi sebesar rs=0,556. Nilai koefisien korelasi tersebut menandakan bahwa terdapat hubungan yang positif antara variabel dukungan sosial orang tua dengan variabel motivasi belajar. Semakin tinggi dukungan sosial orang tua maka semakin tinggi motivasi belajar. Hal yang sama juga berlaku sebaliknya, semakin rendah dukungan sosial orang tua maka semakin rendah motivasi belajar.

Pencapaian hasil belajar mahasiswa tidak hanya dipengaruhi oleh stres saja, namun terdapat hal lain yang ikut mempengaruhi yaitu motivasi belajar (Rucker, 2012). Keadaan stres negatif pada seseorang akan mengakibatkan mahasiswa menjadi malas dan tidak tertarik melakukan kegiatan. Salah satu bentuk stres negatif yaitu stres akademik (Mumpuni \& Wulandari, 2010). Akibatnya apabila seseorang mengalami stres akan terjadi penurunan minat belajar. Minat belajar yaitu suatu ketertarikan seseorang terhadap pelajaran. Minat belajar merupakan alat yang mendorong seseorang termotivasi dalam belajar (Djamarah, 2011)

Mahasiswa mengalami stres dapat berdampak positif atau negative (Goff, A.M, 2011) Dampak positif dari stres tersebut berupa peningkatan kreativitas dan memicu pengembangan diri, selama stres yang dialami masih dalam batas kapasitas individu tersebut. Dampak negatif dari stres 
dapat berupa penurunan konsentrasi dan pemusatan perhatian selama kuliah, penurunan minat, sebagainya, (Wahyudi, dkk 2015) individu yang mengalami stres akan mengalami perubahan kondisi psikis berupa perasaan gelisah, cemas, mudah marah, gugup, takut, mudah tersinggung dansedih.(Indrawati, 2018).

\section{SIMPULAN}

Berdasarkan hasil analisis dan pembahasan pada bab sebelumnya, maka dapat disimpulkan sebagai berikut : Dari 57 responden sebanyak $25(43,9 \%)$ belajar online kurang baik dan sebanyak 32 $(56,1 \%)$ belajar online baik. Dari 57 responden sebanyak $32(56,1 \%)$ tingkat stres ringan, sebanyak $16(28,1 \%)$ tingkat stres sedang dan $9(15,8 \%)$ tingkat stres berat. Hasil uji statistik diperoleh nilai $\mathrm{p}$ value $=0,000$, yang artinya nilai $p$-value $<$ 0,05 maka dapat disimpulkan ada hubungan belajar online di masa pandemic covid 19 dengan tingkat stresmahasiswa S1 Keperawatan STIKES Baiturrahim Jambi

\section{SARAN}

Disarankan bagi peneliti selanjutnya Diharapkan bagi peneliti selanjutnya untuk dapat meneliti variabel lainnya yang mengarah kepada penelitian bivariat ataupun multivariat.

\section{DAFTAR PUSTAKA}

Ambarwati Dkk, 2017, Gambaran Tingkat Stress Mahasiswa, Jurnal keperawatan Jiwa Universitas Muhammadiyah. Semarang

Barker, A., \& Souisa, H. (2020, March 23). Coronavirus COVID19 death rate in Indonesia is the highest in the world. Experts say it's because reported case numbers are too low Retrieved April 17, 2020, from ABC News:
Emeralda \& Ika, 2017, Hubungan antara dukungan sosial orang tua dengan motivasi belajar pada siswa, Fakultas Psikologi Universitas Diponegoro.

Fitasari, Isna Nur. (2011). Faktor yang Berhubungan dengan Kejadian Stres pada Mahasiswa Fakultas Kesehatan Masyarakat Universitas Airlangga. Surabaya: FKM Airlangga.

Indrawati, 2018, Gambaran stress mahasiswa tingkat akhir dalam penyusunan skripsi, Fakultas Kedokteran UIN Alaudin, Makassar

Harahap, dkk, 2020, Analisis Tingkat Stress Akademik pada mahasiswa selama belajar jarak jauh diasa covid 1, Biblio Couns

Hartaji, 2012, Hubungan tingkat dukungan teman sebaya dengan tingkat stress mahasiswa Semester Akhir, Universitas Medan Area: Sumatera Utara

Hidayat \& Noeraida, 2020, Pengalaman komunikasi siswa melakukan kelas online selama pandemic covid -19, Fakultas kominkasi dan desain URS Bandung

Janna N.I 2016, Gambaran Tingkat Stres pada anak usia sekolah denga hospitalisasi di RSUD Labuang Baji, Fakultas Kedokteran UIN Alaudin, Makassar

Kemenkes RI, 2020, Pedoman pencegahan dan pengendalian coronavirus dissae

Kuntarto Eko, 2020, Keefektifan Model Pembelajaran Daring Dalam Perkuliahan Bahasa Indonesia di Perguruan Tinggi, Journal Indonesian Language Education and Literature, Jambi 
Lailiya Wardani, 2018, Pengaruh Tingkat Stress terhadap proses penyelesaian skripsi pada mahasiswa pendidika agama Islam Universitas Islam Indonesia, Fakultas studi pendidikan agama Islam, UII, Yogyakarta.

Masturoh dan Anggita, 2018, Metodologi Penelitian Kesehatan, Pusat pendidikan sumber daya manusia kesehatan

Notoatmodjo, 2012, Metodologi Penelitian Kesehatan. Rineka Cipta. Jakarta

Pawicara \& Conilie, 2020, Analisi Pembelajaran Daring Terhadap Kejenuhan belajar mahasiswa Tadiris Biologi IAIN JEMBER DI TENGAH PANDEMI COVID 19, IAIN : Jember.

Rucker, J. 2012. The relationship between motivation, perceived stress and academic achievement in students [thesis]. Enschede:

Sanajaya F.R, 2020, 21 Refleksi Pembelajaran Daring Di Masa
Darurat, Universitas Katolik SoegijaPranata. Semarang

Sari M.K, 2020, Tingkat Stres Mahasiswa S1 Keperawatan dalam menghadapi wabah coviid 19 dan perkuliahan daring di Stikes Karya Husada Kediri STIKES KARYA HUSADA,

Setiawan A.R 2020, Scientific Literacy Worksheets for Distance Learning in the Topic of Coronavirus 2019 (COVID19), Reading Academic Articels, Kudus

Wahyudi, dkk, 2015, Gambaran Tingkat stress pada mahasiswa fakultas kedokteran Universitas Riau, Fakultas kedokteran Riau : Riau

Yusuf Thalia, 2020, Gaya hidup orang percaya berlandaskan Mazmur 91 : 1-16 dalam menyikapi masalah virus corona (Covid-19) masa kini, Institut Agama Kristen Negeri Toraja, Sulawesi Selatan 